\title{
THD Reduction and Power Quality Improvement in Grid Connected PV System
}

\author{
Rajbir Sood \\ M.Tech Scholar, Elect. Engg. Department, \\ BUEST, Baddi, India
}

\author{
Geena Kalpesh \\ Professor, \\ BUEST, Baddi, India
}

\begin{abstract}
In this paper an MPPT technique is applied in grid connected PV system to harness maximum available power available from sun. The shortcomings of current inverter functions which link PV systems to the utility network are becoming transparent as PV penetration levels continue to increase. In this paper an analysis of solar system connected with the grid has been done.
\end{abstract}

The system is subjected with two types of perturbations, i.e. variable load and the variable irradiance level which changes the output of the solar system. The design, modeling, and analysis of a gridtied PV system are performed in the MATLAB software simulation environment. Solar cell works on the principle of photo voltaic effect, which has nonlinear voltage and current characteristics. These characteristics are improved with the help of maximum power point tracking (MPPT) controller. MPPT controller helps to feed the inverter with maximum power from the solar system. Results indicate that in the presence of grid disturbances the inverter can react dynamically to help restore the power system back to its normal state. A harmonic analysis was also performed indicating the inverter under study met the applicable power quality standards for distributed energy resources.

KEYWORD : photovoltaic system, maximum power point tracking, power quality improvement, total harmonic distortion

\section{INTRODUCTION}

Amongst the renewable source of energy, the photovoltaic power systems are gaining popularity, with heavy demand in energy sector and to reduce environmental pollution around caused due to excess use non-renewable source of energy. Several system structures are designed for grid connected PV systems. Four different kinds of system configuration are used for grid connected PV power application: the centralized inverter system, the string inverter system, the multi-string inverter system and the module integrated inverter system.

The main advantages of using a grid connected PV systems are: effect on the environment is low, the can be installed near to the consumer, thereby transmission lines losses can be saved, cost of maintenance in the generating system can be reduced as there are no moving parts, system's modularity will allow the installed capacity to expand and carbondioxide gases are not emitted to the environment. By year 2020 the European Union aims to get $20 \%$ of its energy from renewable sources [1]. One of the technologies helping EU reach this goal is photovoltaic (PV) power generation, which has grown rapidly in Europe due to governmental support. PV systems are a competitive alternative to other renewable sources currently because of subsidies and in some countries like Germany they can even compete with building new fossil fuel plants. The International Energy Agency (IEA) PV power systems programme registered that approximately $39.9 \mathrm{GW}$ of PV systems was installed over the world throughout 2013, which was an increase of $7.9 \mathrm{GW}$ compared to the past two years. The PV installations in Europe decreased that year, installing only 10.3 $\mathrm{GW}$ compared to $17 \mathrm{GW}$ in 2012. China was the country installing most PV systems in the world in 2013 with its $11.3 \mathrm{GW}$ compared to Germany with $3.3 \mathrm{GW}$ and Norway with 0.6 MW [2]. The current installed capacity of renewable sources of energy (wind, solar, biomass and small hydro) in India is also around $29 \mathrm{GW}$, while the total potential of renewable in the country up to the year 2032 is projected to be $106 \mathrm{GW}$ [3]. Grid connected systems have not been widely developed due to both technical and economic barriers with no support from the government. Getting concession to feed energy into the grid has been a relatively complicated process suited for professional electricity producers. 
A lot of research is being going on this area, but still the effective utilization of solar energy is not happening. This thing motivates us to work on extract maximum power from the solar cell, and to connect the solar cell effectively to the grid, and to contribute our way of thoughts towards the power quality improvement of the system, when a solar cell is connected to the grid. Ramakishan et.al [4] has implemented the simulation cell modelling using single diode model representation, the results are verified using MATLAB/Simulink. Xuosong zhou et.al [5] has given the detailed information regarding the implementation of maximum power point tracking method and compared the results. Hamad et. al [6] has given the detailed information regarding the connection of solar cell to the grid and to improve the power factor using fuzzy logic controller. Kelesidas.K et. al[7] discussed about the p-q based reactive power compensation theory. Which is required for the linear and nonlinear type of loads. This theory gives the detailed information about the compensation of reactive power requirement at the load side, this theory can give the detailed information regarding the compensation of harmonic component of current. The simulation of the solar using simscape model is guided from N.C.sahoo et.al [8], gives the brief description of how to model the solar cell using MATLAB/Simulink using simscape. The maximum power point application to the solar cell using MATLAB/Simulink is guided effectively K.Prabha et. al [9], gives the brief modeling reference for maximum power point technique. The filtering of harmonics presented in the load when nonlinear loads are used, can be eliminated using filtering Jinjun et. al [10], gives the filtering circuit for the elimination of harmonics. The Maximum power points tracking using perturbs and observe method is simulated by taking reference B.Subuddi et. $\mathrm{Al}$ [11],[12] gives the brief description of different types of mppt techniques, and the implementation of maximum power tracking using MATLAB/Simulink method. And he boosts converter operation and the control using maximum power point technique is effectively taken using Y. Zhihao et. al [13], gives the brief description about the boost converter operation and its application to raise the voltage level, from existing voltage. The inverter operation and its connection to the grid is given using Hamad et. al[6]. This is about the literature survey regarding the power quality improvement of single phase grid connected grid connected photo voltaic system.

\section{MODELLING OF GRID-CONNECTED POWER SYSTEM}

\section{Solar cell modelling}

Solar cell can be modeled as current source (Iph) in parallel with Diode (D), Shunt resistance (Rsh) and series resistance (Rse).Current and voltage profile of the solar cell depends on Atmosphere temperature (T), and irradiance $(\mathrm{S})$. The output power of Photo voltaic cell is given by $\mathrm{P}=\mathrm{V} * \mathrm{I}$. The current produced by the $\mathrm{PV}$ cell is equal to the current produced by the current source minus the diode and shunt resistance current. The light generated current of Photo voltaic cell depends on the solar irradiation and the temperature.

$I=I p h-I d-I s h$

$I p h=[I S C+K i *(T-T r)] * \frac{S}{1000}$

$I d=I o\left(e^{\frac{q\left(v+i^{*} R s\right.}{A K T}}-1\right)$

$I o=I o r *\left(\frac{T}{T r}\right)^{3} *\left(e^{\frac{q^{*} E g^{*}\left(\frac{1}{T r}-\frac{1}{T}\right)}{A^{*} K}}\right)$

$\mathrm{I}=$ output current of the PV cell.

$\mathrm{Iph}=$ cell generated current $\mathrm{Id}=$ Diode current

Ish=current drawn by the shunt resistance

Isc=short circuit of the PV cell.

$\mathrm{Ki}=$ short circuit temp coefficient of cell $(0.0032 \mathrm{~A} / \mathrm{k}($ approx...) $) \quad \mathrm{T}=$ module $\quad$ operating temperature in kelvin

$\mathrm{Tr}=$ reference temperature in kelvin $=298 \mathrm{k}$

$\mathrm{Q}=$ charge of electron $=1.9 * 10-19$

$\mathrm{S}=$ module irradiance $(\omega / \mathrm{m} 2)$

$\mathrm{Eg}=$ energy band gap=1.1ev A=ideality factor=1.6

$\mathrm{K}=$ Boltzmann constant=1.38 $* 10-23$.

The important parameters of solar cell are open circuit voltage (Voc), short circuit current (Isc), Maximum Output power (Pmax). 


\section{Maximum Power Point Tracking}

The efficiency of solar cell is low, in order to increase the efficiency maximum power tracking algorithms are used, for getting maximum possible power from the varying source. In photo voltaic power generation the I-V characteristics are non-linear, there feeding power to a certain load. This can be improved by using Boost converter whose duty cycle is controlled by using MPPT algorithm.

The I-V, P-V characteristics the solar cell are shown as the figure below, which are non linear in nature. The power is zero at the starting and at the final value of the curve. Because the non occurrence of the maximum current and voltage at a same point, so as to maintain the operating point at a maximum power value a specially designed technique is required that is maximum power point technique.

In the perturb and observe method of MPPT (used in this work) directly power is measured using voltage and current sensors. The power is calculated from the voltage and current values at Nth instant. By incrementing the values of duty cycle by a small ratio the voltage and current values will be measured at $\mathrm{N}+1$ th instant. The power value at $\mathrm{Nth}$ instant and $\mathrm{N}+1$ th instant will be compared. If the change in the power with respect to the positive then the process is going in the correct direction, that is the positive direction. The duty cycle will be increased by a small ratio and the process will be continued for the next cycle. If the power with respect to voltage is negative then the process is going after the maximum power in the negative direction. In that case the duty cycle will be decreased and the values will be updated for operation.

$\frac{d P}{d V}=0$, Then the slope of the characteristics is zero.

The operation is taking place at the maximum power point. Then no correction is required, the power supplied from the cell is the maximum value.

$\frac{d P}{d V}>0$ The slope of the characteristic is positive, for getting maximum power operation the duty cycle of the converter will be increased, and the values of the voltage and current will be measured. The slope will be measured at the next cycles.

$\frac{d P}{d V}<0$, Then the slope of the characteristics is negative. It is operating at a point after the maximum power point. For getting the maximum power operation the duty cycle of the converter will be decreased. And the voltage and the current values will be measured from them the power will be calculated, and this power will be compared with the previous value, this process will be continued for the next cycles.

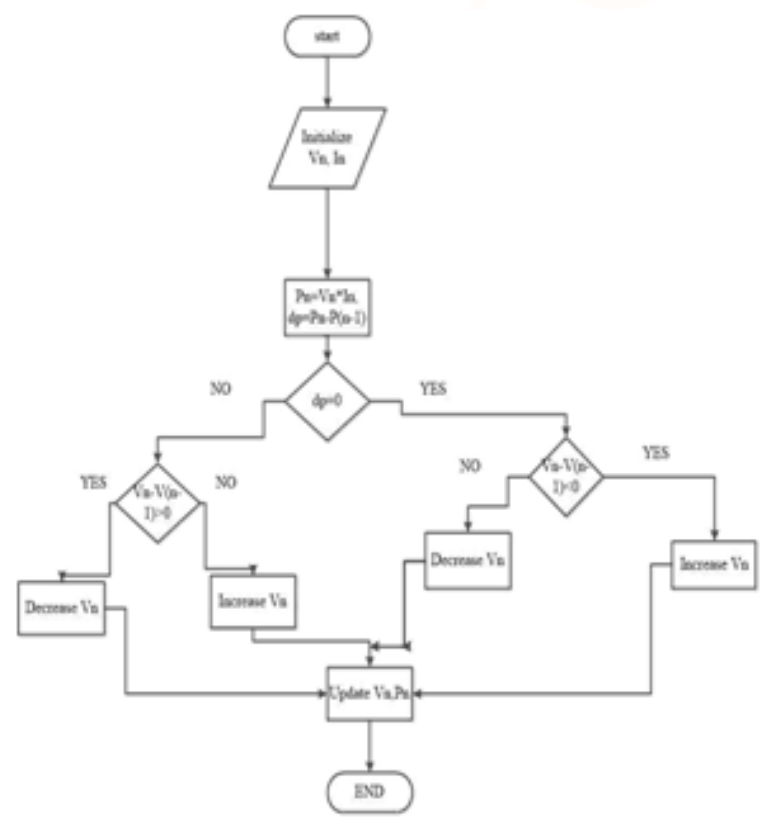

Fig.1. Flow chart diagram for perturb and observe method

The P\&O MPPT method has following characteristics:

- Control strategy is simple for this method.

- Voltage and current are the control variables.

- This method can be applied for the analog and digital modes.

- No parameter tuning is required.

- Cost for implementing this method is high.

- Complexity level of this circuit is high.

- Useful for stand-alone type systems.

- Type of converters used is DC-DC converters.

- Not suitable when the atmosphere conditions are changing rapidly.

\section{RESULTS AND DISCUSSOIN}

The grid connected PV system is subjected to different perturbances such as continuously variable load and variable irradiance level. In this work the system is studied under these two perturbances. The 
two cases are formed to analyze the system performance, these are:

1. Change in irradiance level.

2. Change in the value of three phase load.

The simulation is done for the two seconds and divided in the two parts of one second each. In the first part the irradiation level is changed. From the time 0 sec. $-0.3 \mathrm{sec}$ the irradiance level is $600 \mathrm{KW} / \mathrm{m} 2$, from time $0.3 \mathrm{sec}$. to $0.5 \mathrm{sec}$. it is $700 \mathrm{KW} / \mathrm{m} 2$, from 0.5 to 0.6 it is $800 \mathrm{KW} / \mathrm{m} 2$ and from time $0.6 \mathrm{sec}$. to $2.0 \mathrm{sec}$. the irradiance level is $1000 \mathrm{KW} / \mathrm{m} 2$.

For the second case the value of the three phase load is change in the second part of the simulation i.e. at time 1.5 second and load is made double $(14.65 \mathrm{KW}$ to $25.95 \mathrm{KW}$ ).

\section{Change in irradiance level and Load}

As mentioned above the irradiance level is varied at time $0.3 \mathrm{sec}, 0.5$ and $0.6 \mathrm{sec}$ and load at $1.5 \mathrm{sec}$. The various results obtained are shown in the following waveforms.

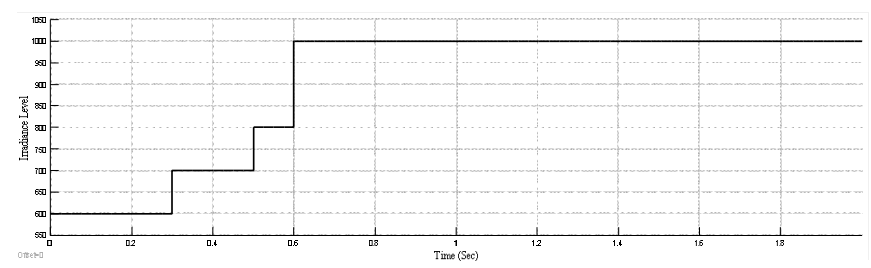

Fig. 2 Irradiance level

The irradiance level is changed as shown in the figure. From time 0.0 to $0.3 \mathrm{sec}$ irradiance value is 600 $\mathrm{KW} / \mathrm{m}^{2}$. The between time 0.3 to $0.5 \mathrm{sec}$. it is 700 $\mathrm{KW} / \mathrm{m}^{2}$, between time 0.5 to $0.6 \mathrm{sec}$. it is $800 \mathrm{KW} / \mathrm{m}^{2}$ and between time 0.6 to $2 \mathrm{sec}$. it is $1000 \mathrm{KW} / \mathrm{m}^{2}$.

As the irradiance level is changed the power generated by the PV system is also varied accordingly. Fig 3 shows the three phase inverter current. From this waveform it is found that as the irradiance level increases the inverter current also increases. This is also verified from the fig. 5. In this fig. the waveforms of the active and reactive power generated by the PV system are shown. The active power increases at time $0.3,0.5,0.6 \mathrm{sec}$. when the irradiance level is increased.

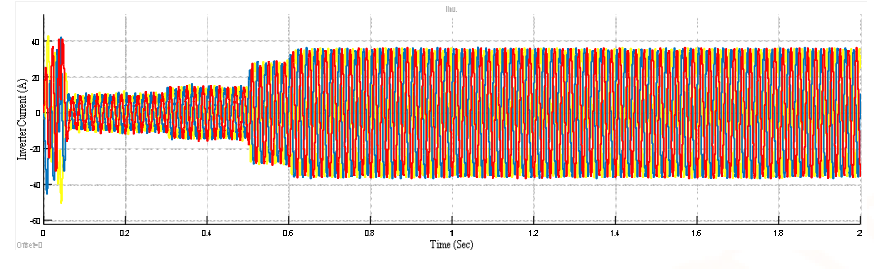

Fig. 3. Three phase inverter current

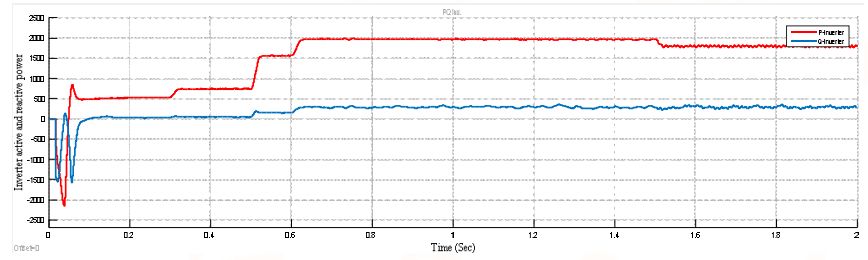

Fig. 4 Inverter active and reactive power

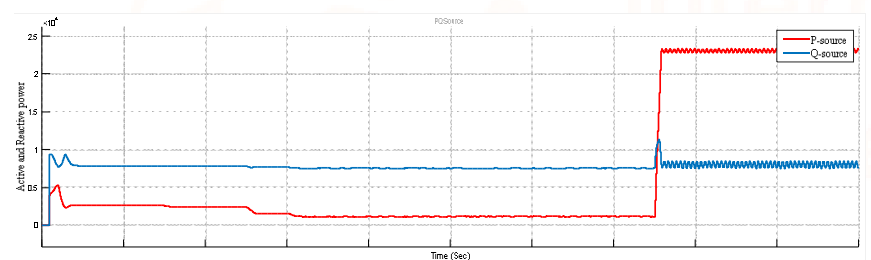

Fig. 5 Source active and reactive power

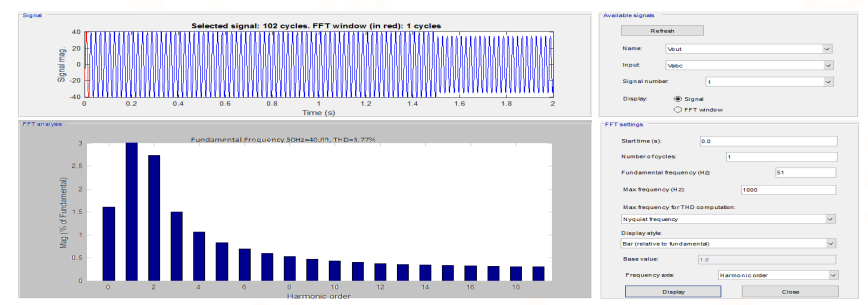

Fig. 6 THD analysis of grid connected PV system

Fig. 6 show the THD found in the system and it is to be $3.77 \%$, which is well below the $5 \%$ prescribed limit.

\section{CONCLUSION}

This work gives the modeling and simulation of grid connected solar power system. And the output voltage and current, output power versus voltage are observed at different irradiance and load conditions. The maximum power variation with the parameters is 
observed. The MPPT techniques for photovoltaic cells are developed and the characteristics are observed at different irradiance level are observed. The boost converter applying the maximum power point technique based on $\mathrm{P} \& \mathrm{O}$ method is explained. The operation of boost converter at different operating conditions like turn on and turn off conditions are observed. The input and output voltages applied for the boost converters are shown and its importance is explained. The combination of boost converter with maximum power point tracking controller makes the converter to obtain the maximum power from solar cell. The operation of the inverter is explained with its different operating modes are the graphs for currentvoltage and power to voltage is observed under different methods.

The comparison is carried out between different cases. The THD analysis is made for the two cases when the irradiance level is low and load is high and vice-versa. It is found that when irradiance level increases the penetration level of the PV system also increases.

\section{REFERENCES}

[1] European Commission. Renewable energy. http://ec.europa.eu/energy/renewables/ index_en.htm, Last accessed January 2016.

[2] IEA International Energy Agency. PVPS Report snapshot of Global PV 1992-2013 - Preliminary Trends Information from the IEA PVPS Programme. http://www.iea-pvps. org/index.php?id=3\&eID=dam_frontend_push\&d ocID=1924, Last accessed May 2016.

[3] Renewable Energy in India 2013- An overview, Indo-German Forum Support Office. Last accessed May 2016.

[4] Rama krishan, Yang raj sood, Uday Kumar, "Simulation and design for analysis of photovoltaic system based on matlab," pp.647$651,2011$.

[5] Xuosong Zhou, Daichun Song, Youjie Ma, Ceng Deshu, "simulation and design based for MPPT of PV system based on incremental conductance method", international conference on information engineering, pp.314-317,2010.
[6] Hamad, M.S, Fahmy, A.M andabdel-geliel,M, M, "Power quality improvement of single phase grid connected PV system with Fuzzy MPPT controller," in Arab academy for science, technology and maritime transport(AASTMT).,pp. 1839-1842., 2013

[7] Kelesidas.K, Adamidis.G, Tsengenes.g, "Investigation of a control scheme based on modified p-q theory for single phase single stage grid connected PV," pp.535-540.

[8] N. C. Sahoo, I. Elamvazuthi, Nursyarizal Mohd Nor, P. Sebastian and B. P. Lim,' PV Panel Modelling using Simscape,"pp.10-14,2011.

[9] Prabha K,Malathi T,Muruganandam M, "Power quality improvement in single phase grid connected nonlinear loads", vol.4, no.3, pp. 12691276, 2015.

[10] Jinjun liu, jun yang, Zhaon Wong, "a new approach for single phase grid connected harmonic current detection and its application in hybrid active power filter,"

[11] Bidyadhar Subudhi, Raseswari Pradhan, "A Comparative study on maximum power point tracking techniques for photovoltaic systems,"IEEE transactions on sustainable energy., vol.4, no.1,pp. 89-98,January2013.

[12] N. Femia, G. petrone, V. Spagnuolo, M. Vitelli, 'Optimization of Perturb and Observe maximum Power Point Tracking Method', IEEE Trans. on Power Electron., Vol. 20, No. 4, July 2005.

[13] Y. Zhihao, W. Xiaobo: 'Compensation loop design of a photovoltaic system based on constant voltage MPPT'. Power and Energy Engineering Conf., APPEEC 2009, Asia-Pacific, pp. 1- 4, March 2009 